\title{
PENERAPAN MODEL PEMBELAJARAN TEAM GAME TOURNAMENT (TGT) UNTUK MENINGKATKAN HASIL BELAJAR
}

\author{
I Wayan Sugiata
}

Univrsitas Negeri Malang

\section{A R T I C L E I N F O \\ Article history: \\ Received 17 April 2018 \\ Received in revised form 26 October 2018 \\ Accepted 12 October 2018 \\ Available online 20 October 2018}

Kata Kunci:

Team Game Tournament (TGT), learning outcomes, reaction rates

\begin{abstract}
A B S T R A K
Pembelajaran di dalam kelas merupakan bagian yang sangat penting dari proses pendidikan. Jika pelaksanaan pembelajaran di kelas bermutu akan menghasilkan output yang berkualitas. Guru memiliki peran yang sangat besar dalam mengorganisasikan kelas sebagai bagian dari proses pembelajaran dan siswa sebagai subyek yang sedang belajar. Kemampuan guru dalam mengemas suatu rancangan pembelajaran yang bermutu tentu diawali dari persiapan mengajar yang matang. Salah satu upaya yang dilakukan untuk meningkatkan hasil belajar peserta didik adalah dengan menerapkan suatu model pembelajaran yang diharapkan mampu mengurangi atau bahkan menghilangkan kesulitan peserta didik dalam memahami materi laju reaksi. Model pembelajaran yang akan diterapkan adalah Team Game Tournament (TGT). TGT adalah jenis pembelajaran kooperatif yang dirancang untuk mempengaruhi pola interaksi peserta didik dan sebagai alternatif terhadap struktur kelas tradisional. Penelitian ini tergolong penelitian tindakan kelas dua siklus. Jumlah subyek penelitian sebanyak 31 peserta didik kelas XI MIA 6 SMAN 1 Malang. Prosedur pengumpulan data pada penelitian ini adalah tes tertulis dengan soal essay. Berdasarkan analisis data diperoleh prosentase hasil belajar afektif pada siklus I $58,94 \%$ dan pada siklus II meningkat menjadi 90,06\%. Hal ini menandakan penerapan model pembelajaran TGT pada materi laju reaksi dapat terlaksana dengan baik.
\end{abstract}

\section{Pendahuluan}

Kegiatan belajar dalam proses pendidikan dan merupakan kegiatan yang paling pokok. Ini berarti bahwa pencapaian tujuan pendidikan bergantung pada proses belajar yang dialami siswa sebagai peserta didik. Dalam mencapai tujuan pendidikan, banyak komponen-komponen yang mempengaruhi pelaksanaan proses pembelajaran di sekolah, diantaranya kurikulum, guru, model pembelajaran, sumber belajar, serta media belajar yang digunakan (Siti K, dkk, 2013).

Dalam proses pembelajaran, unsur proses belajar memegang peranan yang penting. Unsur proses belajar didalamnya termasuk faktor-faktor yang mempengaruhinya. Faktor-faktor yang mempengaruhi belajar dibedakan menjadi dua golongan yaitu faktor yang ada pada diri organisme itu sendiri yang kita sebut faktor individual dan faktor yang ada di luar individu yang kita sebut faktor sosial. Yang termasuk ke dalam faktor individual antara lain : faktor kematangan/pertumbuhan, kecerdasan, latihan, motivasi, dan faktor pribadi. Sedangkan yang termasuk faktor sosial antara lain faktor keluarga/keadaan rumah tangga, guru dan cara mengajarnya, alat-alat yang dipergunakan dalam belajar-mengajar, lingkungan dan kesempatan yang tersedia, dan motivasi sosial. Faktor guru dan cara mengajarnya termasuk didalamnya yaitu model pembelajaran (Totiana et.al, $2012: 1$ ).

Pembelajaran di dalam kelas merupakan bagian yang sangat penting dari proses pendidikan. Jika pelaksanaan pembelajaran di kelas bermutu akan menghasilkan output yang berkualitas. Guru memiliki peran yang sangat besar dalam mengorganisasikan kelas sebagai bagian dari proses pembelajaran dan siswa sebagai subyek yang sedang belajar. Kemampuan guru dalam mengemas suatu rancangan pembelajaran yang bermutu tentu diawali dari persiapan mengajar yang matang.

Agar dapat menarik perhatian siswa dan supaya siswa aktif kepada pelajaran kimia, maka diperlukan strategi pembelajaran oleh guru. Guru yang kreatif berusaha untuk memilih metode yang serasi dan juga sedapat mungkin diselingi yang baru sehingga murid merasakan adanya kesegaran ketika 
menerima pelajaran di dalam kelas, terhindar dari rasa bosan dan mengantuk, bahkan pelajaran akan dirasakan tidak sulit dan menjadi disenangi karena adanya harmonisasi di dalam pemakaian metode

Model pembelajaran yang bertujuan untuk mengembangkan keaktifan siswa, aspek keterampilan sosial sekaligus aspek kognitif dan aspek sikap siswa adalah model pembelajaran kooperatif (Cooperative Learning). Pembelajaran kooperatif merujuk pada berbagai macam metode pengajaran dimana para siswa bekerja dalam kelompok-kelompok kecil untuk saling membantu satu sama lainnya dalam mempelajari materi pelajaran.

Model pembelajarann kooperatif memberi kesempatan kepada siswa untuk berinteraksi secara terbuka dan memberikan suasana yang menyenangkan sehingga akan tercipta adanya ketergantungan positif, interaksi tatap muka, penilalaian individu, mengembangkan hubungan antar kelompok, penerimaan terhadap teman sekelas yang lemah kemampuan akademiknya, serta meningkatkan rasa harga diri dan kepercayaan diri (Anatri D., dkk, 2012).

Salah satu contoh model pembelajaran kooperatif adalah TGT (Teams Games Tournaments). Model pembelajaran TGT terdiri dari lima langkah yaitu: tahap penyajian kelas, belajar dalam kelompok, permainan, pertandingan dan penghargaan kelompok. Dalam model pembelajaran TGT, belajar dapat dilakukan sambil bermain. Model ini merupakan upaya untuk menciptakan keaktifan semua siswa di dalam kelas. Permainan dapat merangsang minat siswa dalam aktivitas kelas sehingga siswa menjadi termotivasi dan memiliki minat untuk belajar.

TGT adalah salah satu tipe pembelajaran kooperatif yang menempatkan siswa dalam kelompokkelompok belajar yang beranggotakan 3-4 orang siswa yang memiliki kemampuan, jenis, agama dan suku yang berbeda. Pembelajaran tipe TGT melibatkan seluruh siswa tanpa melihat perbedaan. Tipe ini melibatkan peran siswa sebagai tutor sebaya, mengandung penguatan. Aktivitas belajar dalam permainan dirancang dalam pembelajaran TGT memungkinkan siswa dapat belajar lebih rileks disamping menumbuhkan tanggungjawab, kejujuran, kerja sama, persaingan sehat dan keterlibatan belajar.

Berdasar uraian di atas, penyusun memilih untuk melaksanakan penelitian tindakan kelas dengan model pembelajaran TGT pada materi laju reaksi. Penerapan model pembelajaran TGT dalam penelitian ini menggunakan sistem belajar sambil bermain. Dengan adanya game diharapkan siswa lebih aktif dalam belajar kimia serta dapat mengarahkan siswa dalam suasana kerjasama sehingga dapat meningkatkan prestasi belajar siswa

\section{Metode}

Penelitian dilaksanakan pada peserta didik kelas XI MIA 6 SMAN 1 Malang tahun ajaran 2014/2015 dengan jumlah peserta didik 31 yang terdiri dari 16 orang laki-laki dan 18 orang perempuan. Penelitian ini tergolong penelitian tindakan kelas (classroom action research) dengan dua siklus. Masingmasing siklus terdiri atas tahap-tahap perencanaan, tindakan, observasi dan refleksi. Penelitian ini dilakukan dengan tujuan untuk memperbaiki kualitas pembelajaran serta mengatasai berbagai permasalahan yang terdapat di dalam kelas seperti motivasi dan hasil belajar peserta didik. Tahap-tahap penelitian ini dapat dilihat pada Gambar 1.

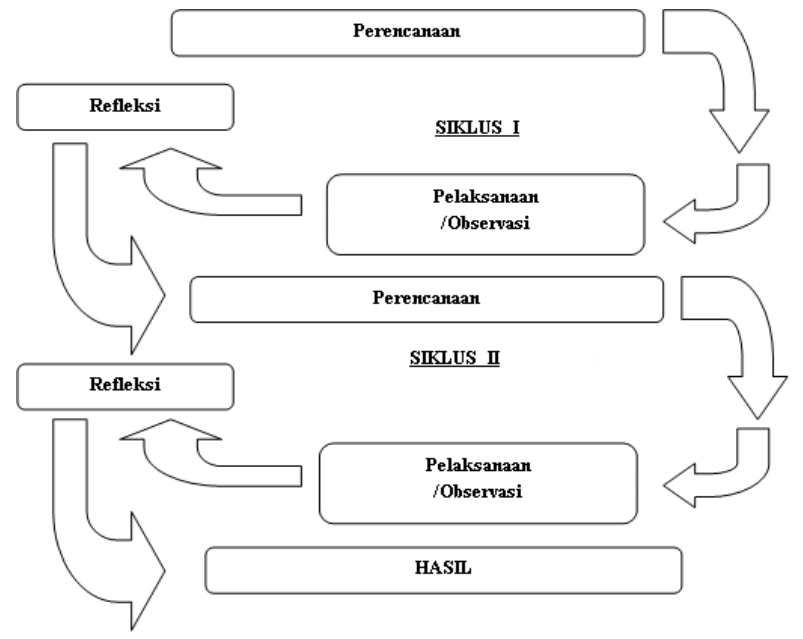

Gambar 1. Tahap-tahap penelitian

Untuk keperluan analisis, maka data-data yang dikumpulkan dalam penelitian ini adalah Data tentang hasil belajar berupa skor tes yang diperoleh melalui tes tertulis bentuk essay tiap akhir pertemuan setiap siklus. Karena yang diukur dalam penelitian ini adalah hasil belajar, maka prosedur 
pengumpulan data adalah dengan tes. Tes dengan soal bentuk essay yang dilakukan setelah pemberian tindakan penerapan model pembelajaran tipe TGT di setiap akhir pertemuan pada setiap siklus. Data yang dianalisis dalam penelitian ini adalah nilai tes kimia pada materi laju reaksi dalam pembelajaran kooperatif tipe Team Game Tournamnet (TGT). Data yang dikumpulkan dan dianalisis secara deskriptif. Secara individual, hasil belajar peserta didik dikatakan telah tuntas belajar jika mencapai KKM 78 dengan perhitungan sebagai berikut :

\section{Skor peserta didik $=\frac{\text { jumlah skor yang diperoleh }}{\text { skor maksimum }} \times 100$}

Nilai ketercapaian peserta didik memiliki rentangan antara 0 sampai dengan 100 yang dikategorikan menjadi 5 taraf keberhasilan seperti yang tertera dalam Tabel 1 berikut ini.

Tabel 1. Nilai Ketercapaian Hasil Belajar Kognitif Peserta didik

\begin{tabular}{lll}
\hline Skor peserta didik & Taraf Keberhasilan & Nilai dengan Huruf \\
\hline $81-100$ & Sangat Baik & A \\
$70-80$ & Baik & B \\
$55-69$ & Cukup & C \\
$30-54$ & Kurang & D \\
$0-29$ & Sangat Kurang & E \\
\hline
\end{tabular}

\section{Hasil dan pembahasan}

Bab ini akan membahas tentang tahapan-tahapan yang dilaksanakan di siklus I dan siklus II. yaitu: (1) tahap perencanaan pembelajaran dengan model Pembelajaran Team Game Tournament (TGT), (2) tahap tindakan pembelajaran dengan model Pembelajaran Team Game Tournament (TGT), (3) observasi tentang keterlaksanaan tahapan-tahapan pembelajaran dengan model Pembelajaran Team Game Tournament (TGT), hasil belajar peserta didik, (4) refleksi keterlaksanaan tahapan-tahapan pembelajaran serta ketercapaian indikator penelitian di setiap siklus.

Siklus I

Proses tindakan yang akan dibahas dalam subbab ini meliputi empat tahap kegiatan yaitu perencanaan, pelaksanaan, observasi, dan refleksi. Masing-masing kegiatan dapat dijelaskan sebagai berikut.

1. Perencanaan Tindakan Siklus I

Pada kegiatan ini beberapa hal yang dilakukan peneliti antara lain sebagai berikut: 1) Menyusun instrumen pembelajaran berupa RPP yang sesuai dengan model pembelajaran Team Game Tournament (TGT), LKPD, dan soal tes, 2) Mengkonsultasikan perangkat yang telah disusun kepada guru pamong dan dosen pembimbing, 3) Membentuk kelompok heterogen beranggotakan 4-5 peserta didik, 4) Menyiapkan kamera sebagai alat dokumentasi.

2. Pelaksanaan Tindakan Siklus I

Dalam pelaksanaan pembelajaran, peneliti mengikuti langkah-langkah untuk mengimplementasikan pembelajaran Team Game Tournamnet (TGT) seperti dalam perencanaan dan sintaks yang terdapat dalam RPP. Setelah diberi nomor untuk masing-masing peserta didik dalam kelompok kemudian dibagikan Lembar Kerja Peserta didik (LKPD), dan peserta didik langsung diminta untuk mendiskusikannya dalam kelompok. Berdasarkan tes hasil belajar pada akhir siklus I, dengan menerapkan model pembelajaran Team Game Tournament (TGT), diperoleh data sebagai berikut.

Tabel2. Data Hasil Belajar Kognitif Peserta Didik Kelas XI MIA 6 Siklus I

\begin{tabular}{cccccc}
\hline Siklus ke- & Jumlah peserta didik & Skor terendah & Skor tertinggi & Rata-rata & \% Ketuntasan \\
\hline I & 31 & 0 & 100 & 72 & $58 \%$ \\
\hline
\end{tabular}

Tabel 2 menunjukkan bahwa pencapaian ketuntasan belajar pada siklus I 18 orang atau 58\%. Data selengkapnya dapat dilihat pada Lampiran 7. Data hasil belajar siklus I ini juga disajikan dalam Gambar 2 


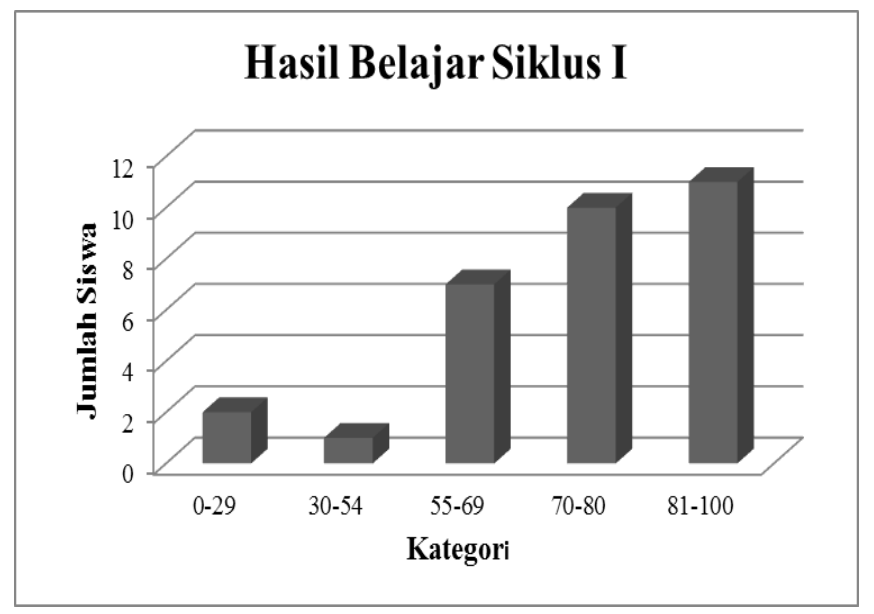

Gambar 2. Hasil belajar siklus I

\section{Siklus II}

Berdasarkan hasil pengamatan dan evaluasi pada siklus I, maka dibuatlah perencanaan revisi yang diimplementasikan di siklus II. Rencana revisi tersebut adalah (a) waktu diskusi lebih dikontrol sehingga tidak menghabiskan jam pelajaran dan pembelajaran dapat diselesaikan pada tiap pertemuan, (b) Peserta didik diberikan banyak latihan soal baik dikerjakan ketika pembelajaran maupun untuk tugas rumah sehingga peserta didik lebih memahami konsep yang ada pada materi laju reaksi, (c) Peserta didik lebih didorong untuk mengoptimumkan unsur-unsur pembelajaran Team Game Tournamnet (TGT). Siklus II dilaksanakan pada tanggal 22 Oktober sampai dengan 5 November 2014. Materi pada siklus II adalah menghitung orde reaksi dan praktikum faktor-faktor yang mempengaruhi laju reaksi.

1) Perencanaan Tindakan Siklus II

Siklus II dilaksanakan dengan model pembelajaran yang sama dengan siklus I yaitu model pembelajaran Team Game Tournamnet (TGT). Perencanaan yang dilakukan sama dengan siklus I, tetap perangkat pembelajaran yang disusun adalah tentang materi menenetukan orde reaksi dan praktikum faktor-faktor yang mempengaruhi laju reaksi. Dalam pelaksanaan siklus II ini terdapat beberapa perubahan berdasarkan hasil refleksi pada siklus I.

2) Pelaksanaan Tindakan Siklus II

Dalam pelaksanaan siklus II ini terdapat beberapa perubahan berdasarkan hasil refleksi pada siklus I. Siklus II dilaksanakan dalam tiga kali pertemuan, yaitu pada tanggal 22 Oktober, 4 November dan 5 November 2014. Materi yang dibahas pada siklus II antara lain menghitung orde reaksi dan praktikum faktor-faktor yang mempengaruhi laju reaksi. Pertemuan pertama dilaksanakan pada hari Selasa, 22 Oktober 2014 di ruang kelas XI MIA 6. Peserta didik yang hadir sebanyak 31 orang.

1) Data Aspek Kognitif

Tingkat pemahaman peserta didik terhadap materi laju reaksi diharapkan lebih baik dari siklus I ke siklus II. Berdasarkan tes hasil belajar pada akhir siklus II, dengan menerapkan model pembelajaran Team Game Tournamnet (TGT), diperoleh data sebagai berikut.

Tabel 3 Data Hasil Belajar Peserta Didik Kelas XI MIA 6 Siklus II

\begin{tabular}{cccccc}
\hline Siklus ke- & Jumlah peserta didik & Skor terendah & Skor tertinggi & Rata-rata & \% Ketuntasan \\
\hline II & 31 & 38 & 100 & 89,8 & $90 \%$ \\
\hline
\end{tabular}

Tabel 3 menunjukkan bahwa pencapaian ketuntasan belajar pada siklus I adalah 90\%. Data selengkapnya dapat dilihat pada Lampiran 8. Data ketuntasan belajar siklus II juga disajikan dalam Gambar 4.8. 


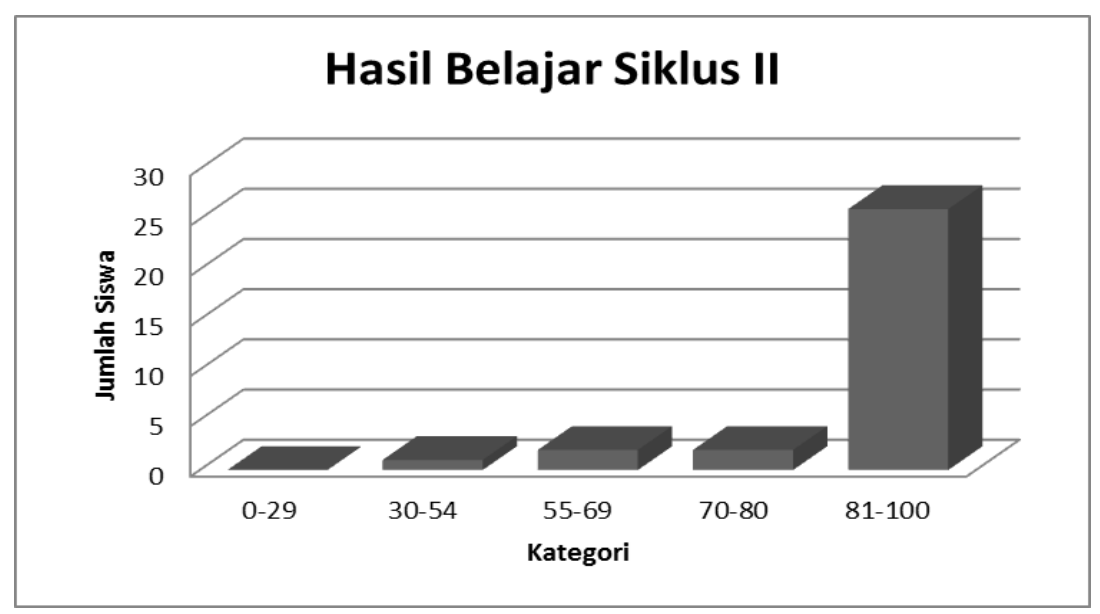

Gambar 3 . hasil belajar siklus II

Untuk mengetahui adanya perubahan tingkat pemahaman peserta didik sebagai dampak dari penerapan model pembelajaran Team Game Tournamnet (TGT), hasil belajar pada akhir siklus II dibandingkan dengan hasil belajar pada siklus I sebagaimana disajikan pada Tabel 4 dan Gambar 4.

Tabel 4.Data Hasil Belajar Peserta didik Siklus I dan Siklus II

\begin{tabular}{clllll}
\hline Siklus ke- & Jumlah peserta didik & Skor terendah & Skor tertinggi & Rata-rata & \% Ketuntasan \\
& & & & & \\
\hline I & 31 & 0 & 100 & 72 & 58,06 \\
II & 31 & 38 & 100 & 85,8 & 90,32 \\
\hline
\end{tabular}

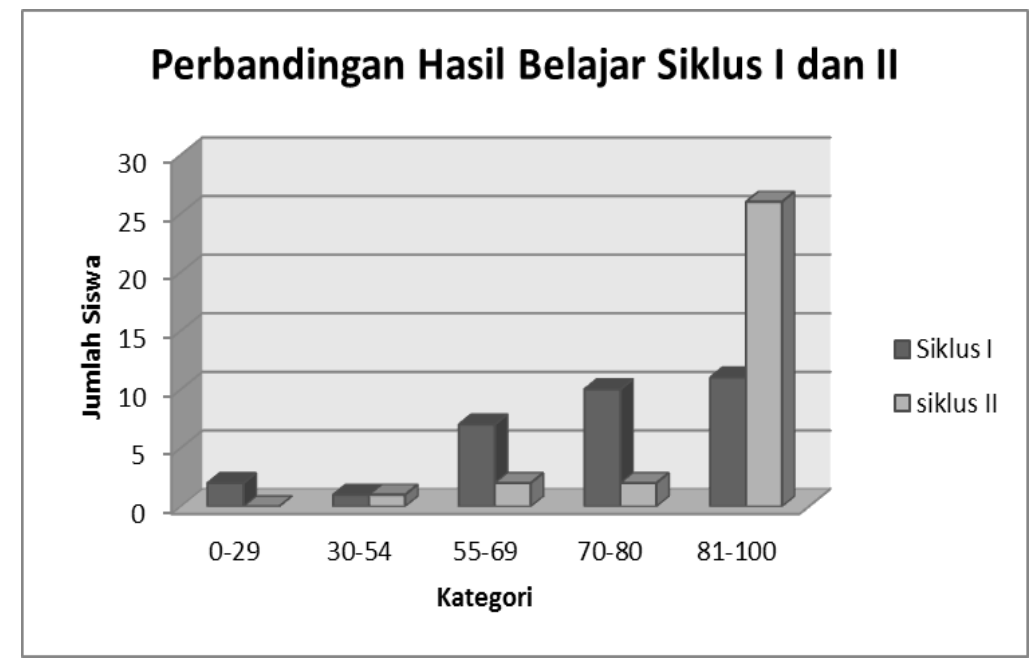

Gambar 4. Perbandingan hasil belajar siklus I dan II

Data di atas menunjukkan bahwa terdapat penurunan jumlah peserta didik yang memilliki rentangan nilai 0-29, 55-69 dan 70-80. Untuk rentangan nilai 0-29 mengalami penurunan dari 2 menjadi 0 peserta didik. Pada rentangan nilai 55-69 mengalami penurunan dari siklus I 6 orang menjadi 2 orang pada siklus II. Begitu juga pada rentangan nilai 70-80 terjadi penurunan dari 8 orang pada siklus I menjadi 2 orang pada siklus II. Artinya peserta didik yang memperoleh nilai pada kategori tersebut berkurang atau mereka memperoleh nilai yang lebih tinggi. Hal tersebut tampak bahwa jumlah peserta didik pada rentangan nilai 81-100 meningkat dibanding pada siklus I yaitu dari 18 orang menjadi 28 orang. Perubahan penting yang tampak adalah jumlah peserta didik yang mencapai KKM 78 (standar sekolah) adalah 28 orang $(90 \%)$. Secara keseluruhan, presentase ketuntasan peserta didik pada akhir siklus I 
adalah 58\% sedangkan pada akhir siklus II naik menjadi 90\%. Keadaan ini mengindikasikan bahwa guru telah menerapkan model pembelajaran TGT lebih baik daripada siklus I

\section{Pembahasan}

Pada bagian pembahasan ini akan dibahas beberapa hal antara lain : (1) tahap tindakan pra siklus, (2) tahap perencanaan pembelajaran dengan model Pembelajaran Teams Games Tournament (TGT), (3) tahap tindakan pembelajaran dengan model pembelajaran TGT (4) observasi tentang keterlaksanaan tahapan-tahapan pembelajaran dengan model Pembelajaran TGT, motivasi dan hasil belajar peserta didik (hasil tes kemampuan konsep), (5) refleksi pembelajaran serta ketercapaian indikator penelitian di setiap siklus. Berikut ini paparan data dari ketiga proses tindakan tersebut.

Peneliti menggunakan data hasil ulangan termokimia sebagai data awal. Hasil belajar awal peserta didik akan digunakan sebagai pembanding pada penentuan dampak pembelajaran dengan menerapkan model pembelajaran yang dipilih. Dari hasil ulangan harian tersebut di kelas XI MIA 6 masih terdapat nilai peserta didik yang kurang dari KKM. Dari kelas yang diampu oleh peneliti (kelas XI MIA 6 dan XI MIA 7), peserta didik yang belum tuntas atau belum mencapai KKM paling banyak adalah kelas XI MIA 6. Perbandingan hasil belajar awal siswa kelas XI MIA 6 disajikan pada Tabel 5.

Tabel 5. Data Hasil Belajar Awal Peserta didik Kelas XI-MIA 6 dan 7

\begin{tabular}{llllllll}
\hline \multirow{2}{*}{ Materi- } & \multirow{2}{*}{ Kelas } & $\begin{array}{l}\text { Jumlah } \\
\text { peserta didik }\end{array}$ & $\begin{array}{l}\text { Skor } \\
\text { terendah }\end{array}$ & $\begin{array}{l}\text { Skor } \\
\text { tertinggi }\end{array}$ & $\begin{array}{l}\text { Rata- } \\
\text { rata }\end{array}$ & $\begin{array}{l}\% \\
\text { Ketuntasan }\end{array}$ & $\begin{array}{l}\text { Rata- } \\
\text { rata } \\
\text { UTS }\end{array}$ \\
\hline \multirow{2}{*}{ Termokimia } & MIA 6 & 31 & 59 & 95 & 82,25 & $97 \%$ & 75 \\
\cline { 2 - 8 } & MIA 7 & 33 & 72 & 99 & 92,45 & $97 \%$ & 86 \\
\hline
\end{tabular}

\section{Deskripsi Siklus I}

Siklus I dilaksanakan pada tanggal 14 Oktober sampai dengan 21 Oktober 2014 pada materi laju reaksi. Materi pada siklus I adalah konsep awal laju reaksi meliputi pengertian laju dan ungkapan laju reaksi serta teori tumbukan. Siklus I dilaksanakan dengan model pembelajaran TGT. Perencanaan pembelajaran materi laju reaksi dibagi ke dalam tiga pertemuan. Pertemuan pertama dan kedua membahas tentang pengertian dan ungkapan laju reaksi. Pertemuan ketiga membahas tentang teori tumbukan dan dilanjutkan dengan memberikan kuis serta posttest untuk siklus I.

Pertemuan 1 Siklus Ke-1

Pertemuan pertama dilaksanakan pada Selasa, 14 oktober 2014 pukul Peserta didik yang hadir sebanyak 31 orang. Pada pertemuan pertama, guru melakukan kegiatan apersepsi dengan memberikan pertanyaan-pertanyaan tentang materi sebelumnya yang merupakan materi prasyarat yaitu reaksi kimia dan molaritas. Selanjutnya, guru dibantu oleh siswa melakukan demontrasi reaksi pembakaran kertas dan reaksi antara $\mathrm{HCl}$ dengan $\mathrm{CaCO}_{3}$. Peserta didik diminta untuk mengklasifikasikan mana reaksi yang berlangsung cepat dan mana yang berlangsung lambat. Langkah selanjutnya adalah penyampaian tujuan pembelajaran, diikuti dengan pembagian pin nomor sesuai kelompok yang telah dibentuk. Guru kemudian membagikan LKPD konsep awal laju reaksi.

Fase I model pembelajaran TGT adalah fase Menyampaikan Informasi (presentasi klasikal). Pada fase ini guru menampilkan grafik reaksi antara gas logam $\mathrm{Mg}$ dengan larutan $\mathrm{HCl}$. Pembelajaran menggunakan media insteraktif laju reaksi dan dilanjutkan dengan menjelaskan secara singkat tentang grafik tersebut.

Fase II model pembelajaran TGT adalah Pembentukan Tim atau Pengorganisasian Kelompok. Pada fase ini guru bertugas membagi kelas menjadi 8 kelompok kecil dengan anggota 4-5 peserta didik untuk tiap kelompok. Guru menampilkan nama-nama kelompok dan anggotanya. Pembagian ini didasarkan pada nilai sebelumnya yaitu termokimia dan hasil UTS. Peserta didik dibagi secara heterogen, artinya dalam satu kelompok terdapat perserta didik dengan kemampuan tinggi, sedang, dan rendah. Selajutnya peserta didik mengerjakan LKPD yang diberikan sebelumnya. Pada kegiatan ini peserta didik mengumpulkan informasi dari segala sumber melalui diskusi kelompok. Pada perencanaannya diskusi dialokasikan waktu sebesar 25 menit, dan guru bertugas membimbing dan memberikan bantuan terbatas kepada kelompok peserta didik yang mengalami kesulitan dalam menemukan konsep laju reaksi. Namun diskusi berjalan melebihi waktu yang direncanakan yaitu 55 menit untuk mendiskusikan pengertian laju reaksi, ungkapan laju reaksi serta perbandingan nilai laju reaksi berdasarkan koefisien pada persamaan reaksi. Hal ini dikarenakan mereka mengalami sedikit kesulitan dalam menemukan konsep sendiri. Peserta didik terbiasai dengan pemberian informasi secara langsung tanpa menggunakan diskusi untuk menemukan konsep. Akibatnya waktu untuk melaksanakan fase III yaitu Permainan (Game Tournament) tidak dapat dilaksanakan. 
Pada fase III, guru hanya meminta peserta didik untuk mempresentasikan atau mengkomunikasikan jawaban LKPD di depan kelas secara singkat. Proses diskusi dan tanya jawab antar kelompok berjalan dengan lancar dengan ditandainya penyaji dan peserta didik tidak ada kesulitan dalam memahami presentasi dari kelompok penyaji.

Pada kegiatan penutup guru menyimpulkan materi yang telah dipelajari bersama dengan peserta didik. Kesimpulan materi terkait adalah pengertian dari laju reaksi, ungkapan laju reaksi serta perbandingan nilai laju reaksi dengan koefisien reaksi pada persamaan reaksi kimia. Guru kemudian melakukan refleksi pembelajaran dengan menanyakan kesulitan-kesulitan apa saja yang peserta didik alami selama kegiatan pembelaran konsep laju reaksi.

Pertemuan 2 Siklus ke-1

Pertemuan kedua dilaksanakan pada Rabu, 15 Oktober 2014 pada pukul 12.15-13.45 WIB (jam ke 7-8) di ruang kelas XI MIA 6. Peserta didik yang hadir sebanyak 31 orang. Kegiatan pada pertemuan ini adalah memantapkan materi pertemuan kemarin mengenai pengertian dan ungkapan laju reaksi. Apersepsi dilakukan dengan menanyakan kepada peserta didik materi sebelumnya yaitu pengertian laju reaksi, ungkapan laju reaksi serta perbandingan nilai laju reaksi terhadap koefisien pada persamaan reaksi.

Pada fase I yaitu fase Menyampaikan Informasi (Presentasi Klasikal) guru menayangkan media interaktif percobaan reaksi Mg dengan $\mathrm{HCl}$. Peserta didik kemudian mengamati dan membaca secara teliti dan diharapkan untuk memberikan pendapat atau menanya terkait tabel hasil percobaan berikut.

Dari hasil pengamatan hanya terdapat dua peserta didik yang memberikan pendapat. Peserta didik pertama menyimpulkan bahwa semakin lama waktu reaksi, semakin sedikit gas hidrogen yang dihasilkan. Pada fase 2 TGT adalah Pembentukan Tim atau Pengorganisasian Kelompok. Guru membagi peserta didik menjadi 8 kelompok dengan masing-masing kelompok beranggotakan 4-5 peserta didik. Guru juga meminta tiap anggota kelompok melakukan tugasnya dengan baik. Guru kemudian membagikan LKPD untuk tiap kelompok. Pemberian dua LKPD bertujuan untuk mengefektifkan penilaian kelompok. LKPD pertama untuk diskusi kelompok sedangkan LKPD kedua dikumpulkan kepada guru.

Pada fase III yaitu Permainan. Guru memberikan soal-soal perhitungan melalui slide power point. Tiap kelompok menjawab soal-soal yang ditayangkan dengan batas waktu tertentu disertai dengan cara pengerjaan soal. Terdapat 5 soal, dan tiap soal berbeda batas pengerjaan waktunya. Permainan berjalan sangat seru karena setiap tim berdiskusi dengan serius dalam mengerjakan soal-soal yang diberikan. Pada fase IV yaitu Pemberian Penghargaan Kelompok, guru memuji beberapa kelompok peserta didik sebagai kelompok terbaik atas dasar penilaian melalui pengamatan kegiatan belajar kelompok.

Pada kegiatan penutup guru bersama dengan seluruh peserta didik menyimpulkan materi yang telah dipelajari. Guru menginstruksikan peserta didik untuk mengerjakan soal individu sebanyak 5 soal selama 15 menit. Guru kemudian melakukan refleksi pembelajaran dengan menanyakan kesulitankesulitan apa saja yang peserta didik alami selama kegiatan pembelaran konsep laju reaksi. Guru kemudian menutup pelajaran dan menyampikan informasi tentang materi pokok untuk pertemuan selanjutnya adalah teori tumbukan.

Pertemuan 3 (Akhir Siklus Pertama)

Pertemuan kedua dilaksanakan pada Rabu, 22 Oktober 2014 pada pukul 12.15-13.45 WIB (jam ke 7-8) di ruang kelas XI MIA 6. Peserta didik yang hadir sebanyak 30 orang. Kegiatan pada pertemuan ini adalah membahas mengenai teori tumbukan. Apersepsi dilakukan dengan menanyakan kepada peserta didik materi sebelumnya yaitu pengertian laju reaksi, ungkapan laju reaksi serta perbandingan nilai laju reaksi terhadap koefisien pada persamaan reaksi.

Pada fase I yaitu fase Menyampaikan Informasi (Presentasi Klasikal) guru menayangkan media interaktif teori tumbukan. Peserta didik kemudian mengamati dan membaca secara teliti dan diharapkan untuk memberikan pendapat atau menanya terkait tabel hasil percobaan berikut.

Pada fase II TGT adalah Pembentukan Tim atau Pengorganisasian Kelompok. Guru membagi peserta didik menjadi 8 kelompok dengan masing-masing kelompok beranggotakan 4-5 peserta didik. Guru juga meminta tiap anggota kelompok melakukan tugasnya dengan baik. Guru kemudian membagikan LKPD untuk tiap kelompok. Pemberian LKPD bertujuan untuk mengefektifkan penilaian kelompok.

Pada fase III yaitu Permainan. Guru memberikan soal-soal perhitungan melalui slide power point. Tiap kelompok menjawab soal-soal yang ditayangkan dengan batas waktu tertentu disertai dengan cara pengerjaan soal. Terdapat 5 soal, dan tiap soal berbeda batas pengerjaan waktunya. Permainan berjalan sangat seru karena setiap tim berdiskusi dengan serius dalam mengerjakan soal-soal yang diberikan. Pada fase IV yaitu Pemberian Penghargaan Kelompok, guru memuji beberapa kelompok peserta didik sebagai kelompok terbaik atas dasar penilaian melalui pengamatan kegiatan belajar kelompok. 
Pada kegiatan penutup guru bersama dengan seluruh peserta didik menyimpulkan materi yang telah dipelajari. Guru menginstruksikan peserta didik untuk mengerjakan soal individu sebanyak 5 soal selama 15 menit. Guru kemudian melakukan refleksi pembelajaran dengan menanyakan kesulitankesulitan apa saja yang peserta didik alami selama kegiatan pembelaran konsep laju reaksi. Guru kemudian menutup pelajaran dan menyampikan informasi tentang materi pokok untuk pertemuan selanjutnya adalah teori tumbukan.

Hasil postes menunjukkan bahwa sebanyak 18 peserta didik tuntas dalam pembelajaran sedangkan 13 peserta didik tidak tuntas dalam pembelajaran. Artinya sebanyak 58,04\% sedangkan sisanya sebanyak $41,96 \%$ tidak tuntas dalam pembelajaran. Dari pembahasan di atas, dapat dibuat tabel deskripsi siklus I sebagai berikut:

Tabel 6. Deskripsi Siklus I

\begin{tabular}{|c|c|c|}
\hline Aktivitas Peserta Didik & $\begin{array}{l}\text { Kemampuan Guru dalam } \\
\text { Pengelolaan Pembelajaran TGT }\end{array}$ & Prestasi Belajar Peserta Didik \\
\hline \begin{tabular}{lr}
\multicolumn{1}{c}{ Aktivitas } & efektif \\
untuk pertemuan 1 dan 2 \\
sebab jumlah & aktivitas \\
positif & meningkat \\
sementara & aktivitas \\
peserta didik & di luar \\
pembelajaran & semakin \\
dapat diminimalkan.
\end{tabular} & $\begin{array}{l}\text { Pengelolaan pembelajaran } \\
\text { pada siklus I belum maksimal, } \\
\text { karena pada pertemuan } 1 \text { tahap } \\
\text { permainan pembelajaran belum } \\
\text { dapat dimunculkan. }\end{array}$ & $\begin{array}{l}\text { Sebanyak } 18 \text { peserta didik } \\
\text { tuntas dalam pembelajaran } \\
\text { sementara } 13 \text { peserta didik lainnya } \\
\text { belum mencapai KKM. }\end{array}$ \\
\hline
\end{tabular}

Deskripsi Siklus II

Pertemuan 1 Siklus ke-2

Pertemuan pertama dilaksanakan pada Selasa, 28 Oktober 2014 pada jam 08.15-09.45 di ruang kelas XI MIA 6. Peserta didik yang hadir sebanyak 31 orang. Kegiatan pada pertemuan ini adalah mempelajari tentang cara menuliskan persamaan laju reaksi dan menghitung orde reaksi. Apersepsi dilakukan dengan menanyakan kepada peserta didik materi sebelumnya yaitu pengertian laju reaksi, ungkapan laju reaksi serta perbandingan nilai laju reaksi terhadap koefisien pada persamaan reaksi. Guru kemudian menyampikan tujuan pembelajaran antara lain: menjelaskan persamaan laju reaksi, menghitung orde suatu reaksi berdasarkan data hasil percobaan; serta menyajikan pemahaman tentang orde reaksi berdasarkan data hasil percobaan.

Pada fase I yaitu fase Menyampaikan Informasi (Presentasi Klasikal) guru menayangkan tabel hasil percobaan perubahan konsentrasi terhadap laju reaksi. Peserta didik kemudian mengamati dan membaca secara teliti dan diharapkan untuk memberikan pendapat atau menanya terkait tabel hasil percobaan berikut.

Tabel 7. Tabel data percobaan reaksi $2 \mathrm{NO}(g)+\mathrm{Cl}_{2}(g) \rightarrow 2 \operatorname{NOCl}(g)$

\begin{tabular}{|c|c|c|c|}
\hline Percobaan & [NO] M & {$\left[\mathrm{Cl}_{2}\right] \mathrm{M}$} & $\mathrm{v}(\mathrm{M} / \mathrm{s})$ \\
\hline 1 & 0,1 & 0,1 & 2 \\
\hline 2 & 0,2 & 0,1 & 8 \\
\hline 3 & 0,2 & 0,2 & 16 \\
\hline 4 & 0,2 & 0,3 & 24 \\
\hline
\end{tabular}

Peserta didik menyimpulkan bahwa pada percobaan 1 dan 2 konsentrasi gas $\mathrm{Cl}_{2}$ tetap sementara konsentrasi gas NO meningkat dua kali, akibatnya laju meningkat empat kali. Sementara pada percobaan 2 dan 3, konsentrasi gas $\mathrm{H}_{2}$ tetap sementara konsentrasi gas NO meningkat dua kali, akibatnya laju reaksi meningkat empat kali.

Pada fase 2 TGT adalah Pembentukan Tim atau Pengorganisasian Kelompok. Guru membagi peserta didik menjadi 8 kelompok dengan masing-masing kelompok beranggotakan 4-5 peserta didik.. Guru juga meminta tiap anggota kelompok melakukan tugasnya dengan baik. Guru kemudian membagikan LKPD untuk tiap kelompok.

Pada fase III yaitu Permainan. Guru memberikan soal-soal perhitungan orde reaksi. Tiap kelompok harus menjawab soal-soal disertai dengan cara pengerjaan soal. Terdapat tiga soal, dan tiap soal berbeda batas pengerjaan waktunya. Permainan berjalan sangat seru karena setiap tim berdiskusi dengan serius dalam mengerjakan soal-soal yang diberikan. Pada fase IV yaitu Pemberian Penghargaan Kelompok, guru 
memuji beberapa kelompok peserta didik sebagai kelompok terbaik atas dasar penilaian melalui pengamatan kegiatan belajar kelompok.

Pada kegiatan penutup guru bersama dengan seluruh peserta didik menyimpulkan materi yang telah dipelajari. Kesimpulan materi adalah pengertian orde reaksi dan cara menentukan orde reaksi dari data hasil percobaan. Guru menginstruksikan peserta didik untuk mengerjakan soal individu sebanyak 3 soal selama 10 menit. Guru kemudian melakukan refleksi pembelajaran dengan menanyakan kesulitankesulitan apa saja yang peserta didik alami selama kegiatan pembelaran konsep laju reaksi. Guru kemudian menutup pelajaran dan menyampikan informasi tentang materi pokok untuk pertemuan selanjutnya adalah faktor-faktor yang mempengaruhi laju reaksi.

Pertemuan 2 Siklus ke-2

Pertemuan kedua Siklus ke-2 dilaksanakan pada Selasa, 4 November 2014 di laboratorium kimia. Seperti biasanya peserta didik yang hadir sebanyak 31 orang. Kegiatan pada pertemuan ini adalah mempelajari tentang faktor-faktor yang mempengaruhi laju reaksi. Apersepsi dilakukan dengan menanyakan kepada peserta didik materi sebelumnya yaitu teori tumbukan. Guru menjelaskan bahwa setiap reaksi dipengaruhi oleh energi. Oleh karena itu kita belajar bagamiana cara memanipulasi keadaan agar laju dapat berlangsung cepat atau lambat. Guru menyampaikan bahwa terdapat beberapa faktor yang mempengaruhi laju reaksi. Guru kemudian menyampaikan tujuan pembelajaran antara lain: menjelaskan faktor-faktor yang mempengaruhi laju reaksi, melakukan percobaan faktor-faktor yang mempengaruhi laju reaksi serta menyajikan hasil pemahaman tentang faktor-faktor yang mempengaruhi laju reaksi.

Pada fase I yaitu fase Menyampaikan Informasi (Presentasi Klasikal) guru menyampaikan penjelasan singkat tentang faktor-faktor yang mempengaruhi laju reaksi serta memberikan LKPD percobaan. Peserta didik kemudian mengamati dan membaca secara teliti dan diharapkan untuk memberikan pendapat atau menanya terkait informasi dari guru dan dalam LKPD tersebut.

Pada fase 2 adalah Pembentukan Tim atau Pengorganisasian Kelompok. Guru membagi peserta didik menjadi 8 kelompok dengan masing-masing kelompok beranggotakan 4-5 peserta didik. Guru juga meminta tiap anggota kelompok melakukan tugasnya dengan baik. Guru kemudian membagikan LKPD untuk tiap kelompok. Selanjutnya peserta didik mengumpulkan informasi tentang faktor-faktor yang mempengaruhi laju reaksi dengan melakukan empat percobaan. Antara lain percobaan pengaruh konsentrasi, pengaruh luas permukaan, pengaruh suhu, dan pengaruh katalis. Karena dilakukan di laboratorium, maka tidak ada permainan. Mengingat sesuai aturan yang terpasan di laboratorium, tidak boleh bermain di laboratorium.

Pada kegiatan penutup guru bersama dengan seluruh peserta didik menyimpulkan materi yang telah dipelajari. Kesimpulan materi adalah teori tumbukan mampu menjelaskan reaksi kimia yang terjadi. Guru kemudian melakukan refleksi pembelajaran dengan menanyakan kesulitan-kesulitan apa saja yang peserta didik alami selama kegiatan pembelaran konsep laju reaksi. Guru kemudian menutup pelajaran dan menyampikan informasi tentang materi pokok untuk pertemuan selanjutnya adalah ulangan harian siklus II

Pertemuan 3 (Akhir Siklus Kedua)

Pertemuan ketiga adalah akhir siklus 2 yang dilaksanakan pada Rabu, 5 November 2014. Pada pertemuan ini dilakukan postes siklus kedua semua materi yaitu orde reaksi dan faktor-faktor yang mempengaruhi laju reaksi. Postes dilakukan selama 60 menit. Hasil postes menunjukkan bahwa sebanyak 28 peserta didik tuntas dalam pembelajaran sementara sebanyak 3 peserta didik tidak tuntas dalam pembelajaran. Artinya sebanyak 90,63\% sementara sebanyak 9,37\% peseta didik tuntas dalam pembelajaran. Dari pembahasan di atas dapat dibuat tabel deskripsi Siklus II sebagai berikut:

Tabel 8. Deskripsi Siklus II

\begin{tabular}{llll}
\hline \multicolumn{2}{l}{ Aktivitas Peserta Didik } & $\begin{array}{l}\text { Kemampuan Guru dalam } \\
\text { Pengelolaan Pembelajaran TGT }\end{array}$ & \multicolumn{2}{c}{ Prestasi Belajar Peserta Didik } \\
\hline Aktivitas efektif untuk & $\begin{array}{l}\text { Pengelolaan pembelajaran pada } \\
\text { pertemuan 1 dan 2 sebab } \\
\text { siklus II sudah maksimal, karena }\end{array}$ & $\begin{array}{l}\text { dalam pembelajaran sementara } 3 \\
\text { peserta didik lainnya belum mencapai }\end{array}$ \\
jumlah aktivitas positif & $\begin{array}{l}\text { setiap tahap pembelajaran sudah } \\
\text { meningkat dan tidak ada } \\
\text { dimunculkan. }\end{array}$ & & \\
aktivitas peserta didik yang & & & \\
negatif (di luar & & & \\
pembelajaran).
\end{tabular}




\section{Simpulan dan saran}

Hasil penelitian yang telah dilakukan, menunjukkan bahwa Penerapan model pembelajaran Team Game Tournamet (TGT) telah meningkatkan hasil belajar peserta didik. Hal ini terbukti bahwa $90 \%$ peserta didik telah mencapai ketuntasan KKM 78 (standar sekolah) dalam materi laju reaksi

Berdasarkan hasil-hasil Penelitian Tindakan Kelas (PTK) ini, maka dapat disarankan kepada para guru bidang studi kimia bahwa model pembelajaran Team Game Tournament (TGT) dapat digunakan secara efektif untuk memecahkan masalah rendahnya hasil belajar kimia khususnya dalam mempelajari materi pokok laju reaksi. Metode yang diterapkan pada penelitian ini juga dapat dicobakan untuk memecahkan masalah pembelajaran kimia pada materi pokok yang lain yang mempunyai karakter yang sama. Lebih lanjut disarankan agar dilakukan Penelitian Tindakan Kelas (PTK) lebih lanjut tentang bagaimana dampak penerapan model pembelajaran Team Game Tournament (TGT) terhadap kemampuan berpikir kritis siswa dalam mempelajari kimia.

\section{Daftar Rujukan}

Anatri Destya, Haryono, Sulistyo Saputro.2012.Pembelajaran Kimia Dengan Metode Team Game Tournament (TGT) Menggunanakan Media Animasi dan Kartu Ditinjau dari Memori dan Gaya Belajar Siswa.Surakarta : JURNAL INKUIRI ISSN : 2252-7893, Vol 1, No 3, 2012 (Hal 177-182). Tersedia pada http://eprints.uns.ac.id/1584/1/145-262-1-SM.pdf. Diakses tanggal 17 Agustus 2014

Diah Megasari Tyasning, Haryono, Nanik Dwi Nurhayati.2012.Penerapan Model Pembelajaran TGT (Teams Games Tournaments) Dilengkapi LKS Untuk Meningkatkan Aktivitas dan Hasil Belajar Materi Minyak Bumi Pada Siswa Kelas X-4 SMA Batik 1 Surakarta Tahun Pelajaran 2011/ 2012.Surakarta: Jurnal Pendidikan Kimia, Vol. 1 No. 1 Tahun 2012 Program Studi Pendidikan Kimia. Tersedia pada http://download.portalgaruda.org/article.php?article=107546\&val=4061. Diakses tanggal 20 Agustus 2014.

Dimyati dan Mudjiono, 2006. Belajar dan Pembelajaran. Jakarta: Rineka Cipta.

Khoirifah, Siti, Ernawati Saptaningrum, Joko Saefan.2013.Pengaruh Pendekatan Problem Solving Model Search, Solve, Create and Share (SSCS) Berbantuan Modul Terhadap Kemampuan Berpikir Kritis Siswa Pada Pokok Bahasan Listrik Dinamis.Semarang : Seminar Nasional 2nd Lontar Physics Forum 2013.2 Tersedia pada http://prosiding.upgrismg.ac.id/index.php/lpf2013/lpf2013/paper/view/136/87._Diakses tanggal 12 Agustus 2014

Luluk Fajri, Kus Sri Martini,Agung Nugroho C.S.,2012.Upaya Peningkatan Proses dan Hasil Belajar Kimia Materi Koloid Melalui Pembelajaran Kooperatif Tipe TGT (Team Game Tournament) Dilengkapi dengan Teka-Teki Silang Bagi Siswa Kelas XI IPA 4 SMA Negeri Boyolali Pada Semester Genap Tahun Ajaran 2011/2012.Surakarta : Jurnal Pendidikan Kimia (JPK), Vol. 1 No. 1 Tahun 2012. Tersedia pada http://eprints.uns.ac.id/11435/1/1062-3379-2-PB.pdf. Diakses tanggal 17 Agustus 2014

Hamalik, O. 2005. Proses Belajar dan Mengajar. Jakarta: Bumi Aksara.

Nur, M dan Prima. 2008. Pengajaran Berpusat kepada Siswa dan

Pendekatan Konstruktivis dalam Pengajaran. Surabaya:

Universitas Negeri Surabaya.

Wiwit, Hermansyah Amir dan Dody Dori Putra.2012. Penerapan Model Pembelajaran Kooperatif Tipe TGT Dengan Dan Tanpa Penggunaan Media Animasi Terhadap Hasil Belajar Kimia Siswa SMA Negeri 9 Kota Bengkulu.Bengkulu: Jurnal Exacta, Vol. X No. 1 Juni 2012. Tersedia pada http://repository.unib.ac.id/495/1/09.\%20Isi\%20vol\%20x\%202012\%20-\%20Wiwit\%20071078.pdf. Diakses tanggal 17 Agustus 2014 